\title{
The Republic Can Never Be Taken for Granted. Ronald J. Oakerson on Vincent Ostrom's Legacy
}

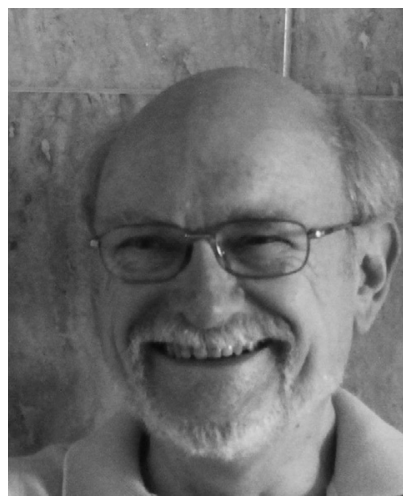

\section{Ronald J. Oakerson}

Professor Emeritus of Political Science at Houghton College (New York, USA); he received the Ph.D. in political science at Indiana University in 1978 with Vincent Ostrom as his committee chair; he served as a member of the National Academy of Science's Panel on Common Property Resources and authored the panel's framework paper, "Analyzing the Commons," in 1986, helping to launch the contemporary study of the commons; in 1989, he was part of the group that founded the International Association for the Study of the Commons; his book, "Governing Local Public Economies" was published in 1999; his most recent work is focused on urban neighborhoods in America and rural villages in Africa as diverse examples of the commons.

$\triangle$ ron.oakerson@houghton.edu https://orcid.org/oooo-0002-7100-6122

\author{
https://doi.org/10.32082/fp.v3i53.306
}

It is now 10 years since the Nobel Prize for Economics was awarded to Elinor Ostrom. We are a few months after the sixth Workshop on the Ostrom Workshop WOW6 at Indiana University in Bloomington, which was attended by researchers from all over the world. In parallel, the International Association on the Study of Commons holds its biennial conference every two years. Most recently in Peru, in two years' time in the United States. It can be said that the Ostroms' heritage is developing dynamically and globally. Research is conducted using a variety of methodologies: from political economy and field research on the management of commons to highly specialized economic, sociological, urban and legal analyses, anthropology, cybersecurity and internet governance, history and media studies. Also in Poland, there is a growing interest in the achievements of the Ostroms' school: new publications are being published and Polish scientists participate in thematic conferences. ${ }^{1}$ The first issue of the

1 Publications, e.g.: K. Safarzynska, The impact of resource uncertainty and intergroup conflict on harvesting in the common-pool resource experiment, „Environmental and resource economics" 2018, vol. 71, no 4, pp. $1001-$ 1025; G. Blicharz, Commons - dobra wspólnie użytkowane: prawnoporównawcze aspekty korzystania z zasobów wodnych [Commons - jointly-used goods: comparative aspects of the use of water resources], Bielsko-Biała 2017; Z. Łapniewska, (Re)claiming space by urban commons, „Review of Radical Political Economics” 2017, vol. 49, no 1, pp. 54-66; G. Blicharz, T. Kisielewicz, Prawne aspekty zarządzania commons wobec technicznych wyzwań rozwoju smart city, "Forum Prawnicze" 2017, vol. 39, no 1, pp. 34-54; K. Safarzynska, Intergroup cooperation prevents resource exhaustion but undermines intra-group cooperation in the common-pool resource experiment, „Ecology and Society” 2017, vol. 22, issue 4:10. Conferences, e.g.: WOW6 2019, Bloomington, IN: Karolina Safarzynska, and Marta Sylwestrzak, "Are Groups Less Cooperative Than Individuals? Groups as Likely as Individuals to Help an Outgroup If It Is Economically Beneficial, but Not under Resource Inequality"; Grzegorz Blicharz, "Legal Aspects of Governing the Commons and Technical Challenges of Smart City Development"; Franciszek Longchamps 


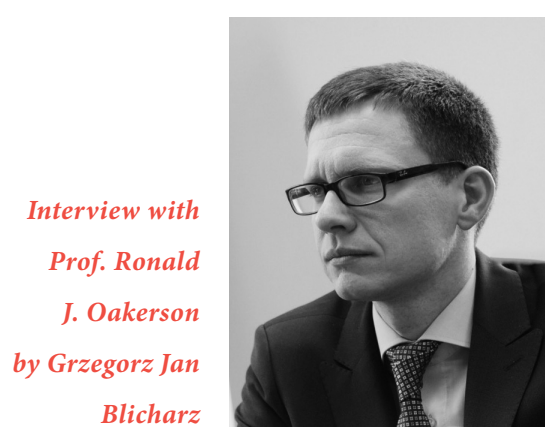

"Legal Forum" journal began with an interview conducted by Prof. Małgorzata Korzycka with Elinor Ostrom - the first female Nobel Prize winner in economics. ${ }^{2}$ From the perspective of these years, we now want to look more closely at the figure of Vincent
Vincent Ostrom's work, later formulated and elaborated by Elinor Ostrom and colleagues as the Institutional Analysis and Development (IAD) framework. ${ }^{5}$ You have in fact accompanied Vincent and Elinor along the way to create and bring up the generations of scholars keen on political thought of Vincent, and Elinor's research on management of the commons.

G.B.: The first research conducted by Vincent Ostrom concerned the management of water resources in Wyoming and in California. Already then, he attached great importance to legal solutions, especially to the jurisprudence of courts. He inspired Elinor to investigate the Pasadena groundwater reservoir case. Where did Vincent Ostrom's interest in the law come from?

\section{What we call "intergovernmental relationships"} are not peripheral arrangements but are at the core of public administration.

Ostrom. His works were also the first to be available to the Polish reader. ${ }^{3}$ Professor Oakerson, your doctoral dissertation ${ }^{4}$ was among the first to develop and apply the core ideas of institutional analysis, drawn from

de Bérier, "Pragmatism, Tolerance, and Compromise: Values behind Governing an Ancient Megaorganization" and Mikołaj Herbst, "The Persistent Legacy of the Fallen Empires: Assessing the Effects of Poland's Historical Partitions on Contemporary Social Norms towards Education”.

2 Wywiad $z$ Elinor Ostrom by Małgorzata Korzycka, „Forum Prawnicze" 2010, vol. 1, no 1, pp. 5-11.

3 V. Ostrom, Administrowanie dobrami i ustugami publicznymi w świetle badań (Public Goods and Public Choices), trans. M. Korzycka, „Administracja” 1989, no 2 = V. Ostrom, Federalizm Amerykański. Tworzenie społeczeństwa samorządnego, Warszawa-Olsztyn 1994, pp. 159-180.

4 R. Oakerson, The Erosion of Public Highways: A Policy Analysis of the Eastern Kentucky Coal-Haul Road Problem (1978), PhD diss., Indiana University, Bloomington. See also R. Oakerson, "Analyzing the Commons: A Framework", in Making
R.O.: Vincent's point of departure on his intellectual journey - his original focus - was the study of public administration, culminating in The Intellectual Crisis in American Public Administration, published in its first edition in 1974. In his study of water administration, he began to see that public administration in America could not be sufficiently well understood through the study of intra-organizational relationships within bureaucratic agencies but, rather, that what we call "intergovernmental relationships" are not peripheral arrangements but are at the core of public administration in the U.S. It followed that public law would come to the fore as the basic coordinating mechanism of such a system, in contrast to a bureaucratic hierar-

the Commons Work: Theory, Practice, and Policy, ed. D.W. Bromley, et. al., San Francisco 1992, pp. 41-59.

5 E. Ostrom, Understanding Institutional Diversity, Princeton 2005; E. Ostrom, Governing the Commons: The Evolution of Institutions for Collective Action, New York 1990. 
chy or chain of command. Somewhat later, Vincent found that Alexis de Tocqueville had addressed the same puzzle in Democracy in America and came to the same conclusion: the enforcement of rights and duties among public agencies at different levels of government in American federalism lies with the courts - an independent judiciary.
R.O.: Good point! The republicans of the founding generation in the U.S. were well aware of the potential for individuals to abuse their liberties; they called such abuse "license." We need to assume that some abuse of speech and press liberties will always occur. To an extent, this is the price we pay for liberty. At the same time, we also know that individuals develop social

\section{We also know that individuals develop social} norms, which constrain the use of liberty and can do so without recourse to governmental coercion.

G.B.: What is the role of law in the concept of a "compound republic"? What is the role of lawyers and judges then?

R.O.: The "compound republic," which is James Madison's phrase, refers to the way in which the separate states, as fully functioning republics, are nested within the general republic called the United States. The U.S. Constitution assigns "enumerated powers" to the Federal Government, while reserving all other powers of government to the states. Given the power of judicial review exercised by the Federal Courts, the Constitution thus exposes any action of the Federal Government to potential legal challenge on constitutional grounds. In addition, the principle of the separation of powers, found at both Federal and State levels in the compound republic, means that administrative actions taken by executive agencies must be authorized by law that is agreed to by independent legislative bodies; this also exposes any administrative action to potential legal challenge in the courts as "ultra vires," not authorized by law. Moreover, the inclusion of a Bill of Rights in both Federal and State constitutions gives individual persons the authority to contest governmental actions in court as potential violations of constitutionally protected liberties.

G.B.: Modern democracies rely heavily on the concept of individual rights and freedoms, which are fundamental. Today, are we not forgetting too often the social dimension of norms, their cultural context and the common good? norms, which constrain the use of liberty and can do so without recourse to governmental coercion. Thus, over time, newspapers have developed standards of journalism that subject members of the press to a form of self-regulation. In the era of electronic social media, however, the abuse of speech and press liberties has reemerged as a critical problem.

G.B.: What role can the media play in a compound republic and what role can especially social media play - do they foster the creation of nested structures?

R.O.: This is one of the great unanswered questions of the day. At present in the U.S., it is the focus of much public discussion. Newspapers historically applied filters to the dissemination of ideas and opinions. Though I have tried numerous times, I have never had a letter to the editor published by the New York Times! Filters can be a source of frustration, but they are an essential means of maintaining the integrity of the press. Our safety valve has been the plurality of press outlets, though even this has been eroded by media consolidation. Today, American politics is continually roiled by the unfiltered expression of opinion that easily reaches mass audiences, a problem for which no clear remedy is in sight. Yet, conceivably, social media could greatly expand public discourse, provided that we can find a way to apply appropriate filters. Vincent was fond of pointing out that, in an assembly, only one person can speak at a time, notwithstanding freedom of speech - implying 
the need for a system of order in assemblies and a way of governing that order. Much the same can be said for expression through social media, which today has produced a cacophony of opinion and disinformation, the reverse of orderly public discourse. republic as constituted by representation. In Federalist 10, Madison contrasted republican governance, by which he meant governance by elected representatives of the people, with democratic governance, meaning governance by the people in assembly. Though the

\section{Though I have tried numerous times, I have} never had a letter to the editor published by the New York Times! Filters can be a source of frustration, but they are an essential means of maintaining the integrity of the press.

G.B.: Today we can observe the formation of closed identity groups, media - people read, watch, listen to those who think in the same way, and those who create, provide information baked for such recipients. In this way, a network of communities is created, but often completely isolated from each other. republic is not composed of the people in assembly, it is nevertheless the people, for Vincent, who compose the republic - as members of the public realm. By this he means a realm of individual and collective action independent of government and thus dependent on willing consent. The defining characteristics of the pub-

\section{Though he was a great admirer of James Madison, Vincent dissented from Madison's view of the republic as constituted by representation.}

R.O.: Yes. Instead of a nested structure of discourse, in which particular identity or opinion groups are nested in a wider exchange of views, creating a conversation across diverse sets of ideas, the public realm is increasingly divided among groups that have little intelligible discourse with one another.

G.B.: You have just mentioned the public realm. Vincent Ostrom perceived the public realm as the core of the republic (res publica). What did he mean by that?

R.O.: Though he was a great admirer of James Madison, Vincent dissented from Madison's view of the lic realm are (1) its openness to individuals and (2) its independence from government.

G.B.: To what extent are the freedoms protected by the First Amendment conducive to the creation of a republic?

R.O.: First Amendment freedoms are in fact constitutive of the public realm. Freedoms of speech, press, and assembly provide individuals with the constitutional authority to create and sustain relationships with one another without prior authorization by government. Any person can challenge government actions that 
infringe upon the public realm by invoking the First Amendment liberties in court.

G.B.: What significance does the freedom of association have for the shape of the contemporary republic?

R.O.: Individuals in association comprise much of the public realm and thus give it structure. Tocqueville saw this clearly in the context of American democracy. Individuals in isolation are relatively powerless, but in
When social relationships are based on willing consent, it is possible for individuals to withdraw their consent. Because individuals depend on the approval of others, they are subject to shared norms of conduct. Social norms - whether standards of journalism that constrain freedom of the press or social manners that constrain freedom of speech - are essential to the public realm. Yet, being based on liberty, the public realm

\section{Yet, being based on liberty, the public realm} must be self-governing; governmental regulation has the potential to destroy it.

association they have the ability to shape the process of governance. The ability to associate without prior authorization by government is essential to the republic.

G.B.: You said recently, "Public freedom is the product of constitutional choice, but social constraint is the product of emerging social norms." Why is social constraint important for our rights and freedoms and where does it come from?

R.O.: Though the public realm is created by constitutional liberties, its productivity depends on social constraint. By definition, the public realm develops independently of government, a product of public liberty. But, as we discussed earlier, liberty (like authority) is subject to abuse. Freedom of speech is abused when it is used to disrupt a lawful assembly. Freedom of the press is abused when it is used to distribute falsehoods. Freedom of assembly is abused when it is used to propagate violence - a mob is not a lawful assembly. The productivity of the public realm therefore depends as much on the restraint of liberty as on liberty itself. But the source of restraint must be primarily social rather than governmental, based largely on social norms rather than the enforcement of law backed by the coercive power of government. Otherwise, the independence of the public realm is lost to governmental regulation. Social constraint is "enforced" not by the extraordinary powers of government but by the ordinary powers of individuals in the context of their social relationships. must be self-governing; governmental regulation has the potential to destroy it.

G.B.: Which idea of Vincent Ostrom is the most important for you?

R.O.: Without question, it is the open public realm, though the idea that draws most attention today is "polycentricity." This is Vincent's supposition that a political system can be composed of numerous semi-autonomous centers of authority, multiorganizational arrangements held together by a rule of law rather than a single sovereign. But the critical importance of polycentricity is that it brings the process of governance into the public realm. As Vincent put it in a paper titled "Federalism, Polycentricity, and Res Publica," delivered at a conference on "Res Publica: East and West" held in Dubrovnik in 1988, "The process of governance occurs in the public space afforded by the concurrent operation of these multiorganizational arrangements." Governance here refers to the whole process of prescribing, invoking, applying, and enforcing rules of law. The separation of powers is a polycentric configuration of

6 V. Ostrom, "Federalism, Polycentricity, and Res Publica: Some Reflections on the American Experiments in Republican Government", in The Practice of Constitutional Development: Vincent Ostrom's Quest to Understand Human Affairs, ed. by F. Sabetti, B. Allen, and M. Sproule-Jones, Lexington Books, 2009 , p. 37. 
authority to govern. In order for government to act, the separation of powers requires that legislative, executive, and judicial officials interact with one another; in order to govern, they must act jointly, in harmony. The interaction of autonomous governmental officials necessarily occurs to some extent in the public realm. Bicameralism, likewise, is a polycentric configuration of authority in a legislature, one that brings the process of the public no longer think they can depend on the press for information and honest discourse, the ability of the public realm to serve as a forum for open discussion and scrutiny of government is seriously weakened. Attacks on the press by high ranking government officials can also lead to intimidation, threatening the independence of the press from government and ultimately the independence of the public realm, in which the press

\section{The primary source of the immediate problem in the U.S. lies in the decline of Congress as a deliberative body.}

of legislation - the process of prescribing law - into the public realm, where members of the public can contribute to the process. Federalism is a polycentric configuration of governmental authority that not only creates multiple governments, compounding the republic, but also creates multiple publics and therefore contributes an important nested structure to the public realm. This is where governance occurs in such a republic: in the public realm, subject to public scrutiny and open to public participation.

G.B.: What are the most important problems of today's American republic and other contemporary democracies?

R.O.: The republic can never be taken for granted. Democratic republics face two perennial problems: one is maintaining the openness of the public realm to the whole public and the independence of the public realm from government; the other is keeping the process of governance firmly embedded in the public realm, where it is visible to the public, rather than allowing it to disappear inside the walls of government. The U.S. is challenged on both fronts today. The openness of the public realm depends on public liberties, including freedom of the press, but the outbreak of an openly adversarial relationship between the highest levels of government and leading press agencies is a troubling development that, by undermining the legitimacy of a free press, potentially threatens its role in the republic. When members is a key institution. An even deeper problem, however, is the difficulty of keeping the process of governance embedded in the public realm. The primary source of the immediate problem in the U.S. lies in the decline of Congress as a deliberative body. Increasingly, legislation is drafted behind closed doors rather than openly in committee deliberations, violating long-standing social norms among members. Closing the legislative process to public scrutiny and foreclosing public participation, opens the door to secret deal-making with private interests - Madison's "factions" - that betray the public good.

G.B.: Are there contemporary threats to the republic from within the public realm? Is political correctness one of them?

R.O.: There definitely are new threats to the republic from within the public realm: the collapse of social norms that previously constrained the political process - the contest for power within the electoral process - and a conception of public liberty in which "anything goes," leading to the decline of public discourse. In this sense, older versions of "political correctness," based on public manners that sustained a sense of mutual respect and civility, are disappearing, replaced by newer versions that often threaten to silence dissenting voices. The fragmentation of the public realm among opinion groups that internally reinforce the views of their members is conducive to a new political correctness that stifles 
the exchange of diverse points of view, which is vital to public discourse.

G.B.: Do religions - communities of believers allow for the creation of a more nested community, often exceeding political differences?

R.O.: When political differences become so great that there is unwillingness to listen to one another across a political divide, discourse based on the free exchange of diverse ideas is threatened. If sufficiently open and diverse, religious communities can soften political differences among their members and make discourse more tolerable, and religious leaders can seek to cultivate these sorts of communities. Counteracting over partisan agendas. In America, this historically has taken the form of an overriding commitment to the Constitution and the rule of law, including an understanding that no political end justifies any and all governmental means. Limitations on the means of governance take priority because it is those limitations that sustain the long-term ability of a people to govern themselves in the public realm. Absent this shared understanding and commitment, it becomes impossible to bridge partisan differences. Admittedly, rebuilding a common understanding of the means of self-governance is the work of at least a generation, not of an election cycle.

\section{When political differences become so great that} there is unwillingness to listen to one another across a political divide, discourse based on the free exchange of diverse ideas is threatened.

this in the U.S., however, is a tendency toward more narrowly sectarian or ideological religious communities, driven perhaps as much by political views as by tradition or theology. Gone are the days when Tocqueville could observe a common body of Christian belief in America, constraining political discourse. Sad to say, in many cases religiosity now tends to fan the flames of divisiveness.

G.B.: In contemporary Poland but also in the United States, there are many divisions of a political nature. There is a very sharp dispute - how can our societies get out of the spiral of what is sometimes even "hatred" to rebuild the social fabric?

R.O.: This is the big question of the day, and I certainly don't have a complete answer. But I think that one component of healing social and political division is to rebuild a shared conception of self-governance and what it entails, fostering a common commitment to its essentials, which includes embedding governance in the open public realm. The basic processes of self-governance must be sustained and take priority
G.B.: In today's politics, much depends on "narration." What role does it play? What does an effective narrative depend on?

R.O.: You're right, political competition consists in great part of competing narratives. Members of the public respond to stories that make intelligible connections between ideas and policies. Policy "wonkery," program details and accompanying analysis, does not make for an effective political campaign. To be effective, a narrative must somehow connect to the experience of listeners, thus making sense to them.

G.B.: In one of your speeches you point out that "We must therefore attend to the stories we tell as much as to the rules we write." How much can the narrative affect the observance of the rules: how can the narrative influence the observance of rules: social, moral, but also legal?

R.O.: Sustaining the public realm is inherently an intergenerational project. Social norms are carried from one generation to the next primarily through the stories we tell and the lessons they convey. Stories concretize 
abstract ideas. Both the abstraction and the illustrative story are important. Institutionalists working in the tradition of Vincent and Elinor Ostrom, including myself, have been focused primarily on "getting the rules right." But the intergenerational transmission of
Analysis (1980) ${ }^{7}$ you presented the methodological basis for research on commons and public policies. From the perspective of time, how do you assess your assumptions from that time, to what extent did they work, to what extent did they need to be modified?

\section{Policy “wonkery," program details and accompanying analysis, does not make for an effective political campaign.}

institutions depends on more than keeping the rules. We must also keep the norms that support the application and enforcement of those rules. The keepers of the republic are not only rule-makers and rule-followers but also story-tellers. Part of what Vincent's concept of the public realm has shown me is that we institutionalists have not told the whole story of the republic. In the midst of an impeachment process in the U.S. House of Representatives, it turns out that the current keepers of the republic are neither politicians nor academics but civil servants who have the courage to speak out, step-
R.O.: What I have been saying about the focus on rules to the exclusion or de-emphasis of norms requires correction. Rules can be formally prescribed and thus directly changed, but not norms. Social norms are an emergent property of institutions, not a design element. Yet, just as we have always tried to anticipate the strategies that individuals will be inclined to choose, given a set of rules, we should also seek to understand the social norms that are likely to follow from the design of an institutional arrangement. Institutional design does more than create what we call the "rules of the game,"

\section{The keepers of the republic are not only rule-makers and rule-followers but also story-tellers.}

ping out of the shadows of bureaucratic administration into the light of public realm. They speak from a lifetime of experience as much as from an abstract set of ideas. It is their concrete experience - their personal story as a governance practitioner - that tells them what they must do in the current, wholly unanticipated circumstance. Their story can now be woven into the larger narrative of the republic.

G.B.: In your pioneering works The Erosion of Public Highways: A Policy Analysis of the Eastern Kentucky Coal-Haul Road Problem (1978) and The Anatomy of Public Problems. Building A Methodology of Policy behavioral do's and don'ts. Institutional design also creates ongoing relationships, and in those relationships individuals can be expected to develop social norms, arising from patterns of approval and disapproval among the members of an interdependent community. Some of those norms actually precede institutional

7 Workshop in Political Theory and Policy Analysis, Indiana University, Bloomington, IN Series:Working Paper, No. W8021 [online] http://dlc.dlib.indiana.edu/dlc/bitstream/handle/10535/4467/roaker03.pdf?sequence=1\&isAllowed=y [last accessed: 26 November 2019]. 
design, at least in an inchoate form, but they remain norms, enforceable through social interaction rather than by third-party determination.

G.B.: Do you consider law (legal norms) as social norms or as rules? Are there legal norms which emerge from ongoing relationships or are they predominantly a design element? for example, the norm that requires executive officers to obey and enforce court orders (absent an enforcement power in the judiciary). In the U.S., these norms have emerged from the relationships created by the constitutional separation of powers. But many of the norms surrounding due process of law also preceded the writing of the U.S. Constitution. This what allowed

\section{Moreover, the legal system - the process of applying and enforcing law - also depends on norms of conduct shared by the legal community.}

R.O.: I consider the content of law to consist of rules, but it should be a coherent body of rules. The whole body of law should fit together in a logical sense, guided by common principles widely shared as norms within the legal community, which consists not only of judges and lawyers but also of law professors and legal critics, who strive for coherence. Moreover, the legal system - the process of applying and enforcing law - also depends on norms of conduct shared by the legal community. Just the drafters of the Fifth Amendment due-process clause to refer abstractly to the concept of due process without any enumeration of its elements. As well, the process of applying law requires reference to shared norms of interpretation (increasingly difficult to sustain in the U.S. as any watcher of the U.S. Supreme Court well knows). There is still much to be explored regarding the relationship of norms to rules in the process of governance. It is an area ripe for inquiry.

\section{Law professors may need to be good story} tellers, highlighting the role of legal actors in maintaining the republic, as well as competent expounders of the law and its basic principles.

as freedom of the press depends on journalistic standards to be productive, and just as "due deliberation" (to use Alexander Hamilton's evocative phrase, often cited by Vincent) depends on norms shared by legislators, so does "due process of law" depend on shared norms among jurists. Furthermore, commitment to the "rule of law" requires norms shared across the separation of powers as well as among members of the public at large,
G.B.: What kind of legal research or legal education do you think is needed in the field of governance and institutional design?

R.O.: I don't feel especially well qualified to answer your question, given that my experience with legal education is limited to the 14 credit hours I earned in the IU School of Law for a graduate minor required for the Ph.D. I enjoyed the case method of instruction, but as 
the exclusive method it is also somewhat limiting. The broader issue, however, is the intergenerational transmission of professional norms. A thorough rethinking of the meaning of the republic, constituted at its core by the open public realm, will entail reassessing how the relevant professions, including the legal profession, transmit professional norms to future generations of practitioners. In addition to reading cases, students of law may need a systematic exposition of the logic of governance by means of law, as well as its institutional requirements, including the application of law to those who exercise prerogatives of government. Instruction in the norms of the legal profession more generally is also important, shared perhaps as much through informal narrative as through systematic exposition. Law professors may need to be good story tellers, highlighting the role of legal actors in maintaining the republic, as well as competent expounders of the law and its basic principles. governance may contain important social assets of use in crafting governance processes adapted to conditions of life in the twenty-first century. Elements of continuity are always important in development, no matter how drastic the change. But it is not just the so-called developing world that stands on the precipice of such change. So does the developed world, in particular, what we call The West. The prevailing global understanding of governance is based on nation-states. Vincent challenged this conception. Though hardly sanguine about the immediate future of the United States, he expected that the "state," based on a monopoly of force, would eventually wither away. He sought to develop an alternative understanding based on the human capability to build much more complex governance structures than the state, expanding and elaborating the public realm as a highly nested structure that can reach deep within state boundaries and well beyond them. But, if the state apparatus manages to prevail, and the public realm is

\section{If the state apparatus manages to prevail, and the public realm is eclipsed, much of the world may enter a new dark age.}

G.B.: What issues in Vincent Ostrom's heritage require special attention and further research?

R.O.: I have been increasingly drawn to the study of governance in developing countries, as was Vincent as his work matured. Perhaps this is because developing countries present the problem of institutional design in its most basic form. Yet, it is also apparent that there is an "organic" quality about institutional development that depends on the institutional base of a country. One never writes new institutions on a blank slate. The travails of much of Sub-Saharan Africa seem to be connected to a widespread disposition to ditch traditional forms of governance in favor of a modern form, generally viewed (in Weberian terms) to require a monopoly of coercive authority in society. The fact that institutional development depends on social norms as much as on rules, however, suggests that traditional patterns of eclipsed, much of the world may enter a new dark age. Vincent has provided important ideas and conceptions for approaching the task of institutional creativity in challenging times. We cannot foresee what may emerge in 200 years. But we can open our minds to alternative possibilities and endeavor to respond creatively - and with requisite courage - to the critical problems at hand, one innovative institutional step at a time.

G.B.: As regards building more complex governance structures than the state - do you think that the sovereignty of states and national identity will play a much lesser role? What kind of shared identity would make people cooperate, or act together?

R.O.: The sources of shared identity vary widely across the peoples of the world. Many of the variables associated with nationality are relevant and important: shared history, language, religion, and other aspects of 
human culture. But there is no one basis for political association. As a result, we should expect the means and scale of association to vary widely. In the world order, there should be a place for various forms of association as the basis for governance - from cities to nations both small and great. The basic organizational principle on which such a world order can be constituted is nestedness (though never as elegant to view as Russian dolls). Much of my empirical work has been concerned with fering scales of organization. Often this will sustain or even strengthen existing national identities, but not always. The demands of sub-national communities for greater autonomy, and of stateless communities for recognition and a means of common governance, are demands that cannot simply be ignored. We can expect both the devolution of some governance functions to communities within existing nation-states and the development of supra-national regimes that assume

\section{We need to be able to articulate more meaningful} concepts of republican governance, so that the organizational nesting that occurs is not merely the nesting of governments but primarily a nesting of communities of citizens, extending and elaborating the structure of the open public realm.

metropolitan organization and governance in the U.S. Many critics of the American system of local government decry its messy appearance on a map. It looks disorderly because the way that governmental units are nested is never uniform across a metropolitan area. The cause of variation is the bottom-up method by which nesting develops, as smaller communities (of various sizes and shapes) create overarching units at various scales of organization. Visual order is not the point. Building mutually productive relationships among varying communities of identity and interest - that is the point. The construction of a mutually productive world order should follow the same pattern, reiterating the process of constitutional choice (as Vincent would say) at dif- particular, well-defined governance functions from their member nations. In the process, concepts of state sovereignty will necessarily become much more attenuated. In their place, we need to be able to articulate more meaningful concepts of republican governance, so that the organizational nesting that occurs is not merely the nesting of governments but primarily a nesting of communities of citizens, extending and elaborating the structure of the open public realm - constituted in public liberty and regulated by shared norms of public conduct. In an increasingly polycentric world, this is where governance will occur, in a public realm of nested communities. 